\title{
ORIENTASI PENDIDIKAN SALAFI: Kasus Pesantren Assunah Kalitanjung Cirebon
}

\author{
Husen Hasan Basri \\ Peneliti Muda Puslitbang Pendidikan Agama dan Keagamaan \\ Badan Litbang dan Diklat Kementerian Agama RI \\ Jl. MH. Thamrin No.6 Jakarta, Email: hhasanbasri@yahoo.com
}

\begin{abstract}
Salafi schools are lately emerging as new model schools. Salafi boarding schools have their own orientation and way of seeing education. Salafi schools genealogically and intellectually have nothing to do with traditional Islamic boarding schools (salafiyah) and other modern boarding schools. The Salafi boarding schools have certain religious ideas which can be connected with the salafi movement in Indonesia and Islamic world. The Salafi boarding schools are experiencing significant growth. One of the Salafi boarding schools is Pesantren Assunah Kalitanjung Cirebon. Assunah boarding school has a positive and negative place amongst the people of Cirebon. In fact, pesantren Assunah has been accused of planting the seeds of violence that leads to terrorism. This research uses a qualitative research approach by interviewing a number of pesantren leaders and preachers of Assunah, organization leaders, representatives of Islamic universities as well as by observing the Assunah boarding school campus, studying the documents that exist in schools, and obtaining data and information relating to the Assunah school. The conclusion is that the Assunah salafi boarding school is carrying out a mission oriented toward an educational culture by implementing the concept of cultural transmission.
\end{abstract}

Keywords: Education Orientation, Salafi Islamic Boarding School, Cultural Transmission.

\section{Abstrak}

Akhir-akhir ini muncul pesantren model baru yang sering disebut "pesantren salafi". Pesantren model salafi memiliki orientasi sendiri dalam cara memandang dan mengartikulasikan pendidikan yang diselenggarakan. Pesantren model salafi secara genealogi dan jaringan intelektual tidak memiliki kaitan dengan pesantren-pesantren tradisional (salafiyah) dan pesantren modern model Gontor dan jaringannya. Pesantren model salafi ini memiliki paham keagamaan tertentu yang dapat dihubungkan dengan gerakan salafi baik di Indonesia maupun di dunia Islam lainnya. Pesantren model salafi ini mengalami perkembangan yang cukup signifikan. Salah satu pesantren salafi adalah Pesantren Assunah Kalitanjung Cirebon. Pesantren Assunah ini mengalami pro dan kontra di kalangan masyarakat Cirebon. Bahkan, Pesantren Assunah pernah dituduh mengajarkan benih-benih kekerasan yang mengarah kepada terorisme. Melalui pendekatan penelitian kualitatif dengan mewawancarai sejumlah pimpinan dan ustadz pesantren Assunah, tokoh ormas, pihak perguruan tinggi Islam; mengobservasi kampus pesantren Assunah; dan mempelajari dokumen-dokumen yang ada di pesantren, didapatkan data dan informasi terkait dengan pesantren Assunah. Dengan menggunakan konsep "cultural transmission", disimpulkan bahwa Pesantren Assunah sedang melakukan misi kontinuitas kultur salafi dalam orientasi pendidikannya.

Keywords: Orientasi Pendidikan, Pesantren Salafi, Cultural Transmission. 


\section{PENDAHULUAN}

\section{Latar Belakang}

Dunia pesantren tampaknya telah mengalami perkembangan secara signifikan. Perkembangan tersebut bukan hanya bersifat kuantitatif yang terlihat dari jumlah kelembagaan dan santri yang terus meningkat, ${ }^{1}$ tetapi juga perkembangan yang bersifat kualitatif antara lain: visi yang dibuat, misi yang dijalankan, program pendidikan yang diselenggarakan, kurikulum yang dipakai, pola kepemimpinan, pengaruh ideologi dan paham keagamaan serta jaringan yang terbangun dengan dunia luar, sampai kepada peran pesantren yang semakin luas (wider mandate). Semua perkembangan kualitatif tersebut merupakan perwujudan dari orientasi pendidikan di suatu pesantren yang dapat melahirkan keragaman model pesantren. ${ }^{2}$

Model pesantren yang saat ini mengalami perkembangan yang cukup signifikan adalah pesantren salafi. Assunah merupakan salah satu dari model Pesantren Salafi yang sudah menjadi sebuah komunitas pendidikan yang memiliki beragam layanan program pendidikan. Eksistensi Pesantren Assunah diawali dengan berdirinya Yayasan Assunah pada tahun 1993. Penamaan pesantren sendiri baru dimulai tahun 2005. Jenis pendidikan pesantren menjadi salah satu bidang kegiatan dibawah Yayasan Assunah. Sistem pesantren ini oleh pendirinya diasosiasikan dengan konsep boarding school

${ }^{1}$ Data yang ada di Kementerian Agama tahun 2003-2004 jumlah pesantren tercatat sebanyak 14.656 orang. Pada tahun 2006-2007 atau 3 tahun kemudian mencapai 17.506 pesantren dengan jumlah santri mencapai 3.289 .141 orang. Pada tahun 2008-2009 atau 2 tahun kemudian mencapai 24.206 pesantren dengan jumlah santri mencapai 3.647.719 orang. Pada tahun 2011-2012 atau 3 tahun kemudian mencapai 27.218 pesantren dengan jumlah santri mencapai 3.643.038 orang.

${ }^{2}$ Hasil pemetaan awal yang bersifat sementara terhadap keragaman model pesantren yang didasarkan kepada orientasi pendidikan setidaknya memperlihatkan empat model pesantren, yaitu: pesantren salafiyah atau tradisional, pesantren modern, pesantren islamis, dan pesantren salafi. yang sebenarnya diperuntukkan untuk siswasiwa tingkat Madrasah Tsanawiyah (MTs) dan Madrasah Aliyah (MA). Sedangkan sistem full day school diperuntukkan untuk siswa-siswa Taman Kanak-Kanak Islam Terpadu (TKIT) dan Sekolah Dasar Islam Terpadu (SDIT).

Transformasi pendidikan yang dilakukan Assunah mendapat resistensi dari beberapa kalangan masyarakat. Resistensi terjadi diduga karena faktor kompetisi antar lembaga pendidikan Islam dalam rangka memperoleh dukungan masyarakat. Apalagi diketahui bahwa Assunah yang menawarkan model pendidikan Islam baru yang cenderung dapat menyebabkan lembaga-lembaga pendidikan Islam yang ada akan kalah bersaing. Bentuk kompetisi yang tidak sehat berlangsung antara lain dengan muncul dan merebaknya data dan informasi keliru yang bertujuan membangun image buruk atau opini publik yang negatif terhadap lembaga pendidikan Islam tersebut dengan tuduhan sebagai lembaga pendidikan yang memiliki dan mengembangkan paham Salafi-Wahabi yang cenderung mengajarkan ajaran kekerasan. Assunah, misalnya, pernah dituduh mengajarkan benih-benih terorisme. Benih-benih terorisme ini, sebagaimana yang dikatakan oleh para penuduhnya, berasal dari ajaran Wahabi seperti pembid'ahan dan pemusyrikan terhadap praktek ziarah kubur, tahlilan, dan haul. ${ }^{3}$ Tuduhan itu kemudian dibantah oleh pihak Assunah. Menurut Ustadz Said Riyana, pihak Assunah tidak pernah menganggap musyrik orang-orang yang tahlilan, apalagi halal darahnya dan boleh dibunuh. Justru di Assunah sangat gencar meluruskan kekeliruan ideologi teroris melalui pengajian dan tabligh akbar. Terkait pelaku bom bunuh diri masjid Polresta Cirebon dan bom Solo, Ustadz Said Riyana mengatakan bahwa para pelaku itu tidak pernah belajar dan bukan lulusan Assunnah. ${ }^{4}$

${ }^{3}$ Lihat merdeka.com, Jumat (28/09) dalam rubrik khas wawancara dengan KH Said Aqil Siraj dengan tema "Ajaran Wahabi Mendorong Orang Menjadi Teroris".

${ }^{4} \mathrm{http}: / /$ www.gemaislam.com/index.php/berita/ indonesia-news-menuitem/599. 
Pro dan kontra telah mewarnai eksistensi dan perkembangan Assunah. Bagi yang pro mengganggap bahwa Assunah adalah lembaga pendidikan yang dianggap bermutu yang bisa melayani kebutuhan pendidikan anak mereka. Meskipun sebagai lembaga pendidikan, bagi yang kontra memandang Assunah sedang menyebarkan paham keagamaan Salafi-Wahabi yang dalam strategi dakwahnya kadangkadang dapat meresahkan masyarakat. Bagi yang kontra, Assunah ini sebenarnya lembaga dakwah yang didalamnya menyelenggarakan beragam program pendidikan yang ditopang oleh hubungan dan jaringan gerakan salafi di Indonesia.

Lepas dariadanya pro dankontra, pesantren berdasarkan UU No. 20 Tahun 2003 dan PP 55 Tahun 2007 telah memperoleh pengakuan sebagai bagian dari sistem pendidikan nasional. Sebagai bagian dari sistem pendidikan nasional, maka tujuan pendidikan di pesantren harus mengacu dan sejalan dengan tujuan pendidikan nasional. ${ }^{5}$ Pengakuan tersebut di satu sisi, pesantren diberikan peluang untuk meningkatkan dan mengembangkan perannya di bidang pendidikan. Pada sisi lain, pemerintah dalam batas-batas tertentu memiliki kewenangan melakukan pembinaan agar pesantren tetap konsisten memberikan pelayanan pendidikan yang mengacu kepada tujuan sistem pendidikan nasional.

\section{Rumusan Masalah}

Berdasarkan latar belakang diatas, permasalahan penelitian (research problems)

${ }^{5}$ UU Sisdiknas Nomor 20 Tahun 2003 Bab II Pasal 3 menyatakan: tujuan pendidikan nasional adalah mengembangkan potensi peserta didik menjadi manusia yang beriman dan bertakwa kepada Tuhan Yang Maha Esa dan berakhlak mulia, sehat, berilmu, cakap, kreatif, mandiri, dan menjadi warganegara yang demokratis dan bertanggung jawab. Dalam PP 55 Tahun 2007 secara eksplisit dirumuskan Pesantren adalah lembaga pendidikan berbasis masyarakat yang menyelenggarakan pendidikan keagamaan Islam dalam pondok pada jalur pendidikan formal dan nonformal. Lebih lanjut dalam PP tersebut disebutkan bahwa Pesantren sebagai pusat pendidikan Islam dapat menyelenggarakan pendidikan terpadu dengan pendidikan umum dan/atau kejuruan pada tingkat dasar, menengah dan tinggi. adalah bagaimana orientasi pendidikan di Pesantren Assunah, baik yang berkaitan dengan pendidikan yang dipahami atau dimaknai (image) maupun pendidikan yang diinginkan atau diharapkan (expectation).

\section{Tujuan dan Kegunaan}

Penelitian ini bertujuan untuk mendekripsikan orientasi pendidikan yang meliputi pemaknaan pendidikan dan harapan terhadap pendidikan yang dibangun di Pesantren Assunah.

Dalam posisi pro dan kontra terhadap Assunah, penelitian ini diharapkan bermanfaat bagi berbagai pihak terkait. Pertama, Kementerian Agama (Direktorat Pendidikan Diniyah dan Pesantren) untuk menetapkan kebijakan terhadap pesantren-pesantren Salafi umumnya dan pesantren Salafi Assunah khususnya yang berkaitan dengan penyelenggaraan pendidikan. Kedua, bagi masyarakat, khususnya wali santri, dapat memperoleh informasi yang benar berkaitan dengan sistem pendidikan di Pesantren Assunah sehingga masyarakat yang berniat memasukan anaknya ke pesantren ini merasa tenang. Secara akademik, penelitian ini dapat melengkapi penelitian-penelitian tentang pesantren Salafi yang telah dilakukan.

\section{KERANGKA TEORI}

\section{Pesantren Salafi}

Sejarah Pesantren Salafi dapat dilacak pada pertengahan tahun 1980-an ketika komunitas salafi pertama terlihat dan berani menyatakan diri. Simbol ekspansi salafi di Indonesia dapat dilihat dari kemunculan laki-laki yang berjanggut memakai jubah panjang (jalabiyya), surban, dan celana di atas mata kaki (isbal), serta perempuan yang memakai cadar hitam (niqab). Perhatian mereka kembali kepada keaslian kepercayaan, tauhid, dan sejumlah isu lain yang terfokus pada panggilan praktek keagamaan yang murni dan integritas moral individu. Komitmen terhadap penggunaan 
jalabiyya dan niqab, misalnya, dipandang lebih penting daripada terlibat dalam aktivitas politik. Mereka percaya bahwa masyarakat muslim pertama kali harus dilakukan islamisasi secara proses evolusi dan bertahap yang salah satunya melalui pendidikan (tarbiyah) dan pemurnian atau purifikasi (tasfiyya) sebelum syariah dapat terrealisasi. ${ }^{6}$

Kemunculan gerakan salafi dan jaringan pesantren salafi di Indonesia merupakan bagian dari ekspansi global dakwah salafi kontemporer yang secara terbuka berafiliasi dengan Negara Saudi Arabia serta pemikiran dan praktik wahabisme. Wahabisme adalah semua nama yang dinisbatkan kepada Muhammad ibn Abd al-Wahhab (1703-1792) yang berkampanye melawan praktik keagamaan yang sudah ada. Wahabisme merupakan model yang kecenderungannya ke arah gerakan permurnian salafi. Dasardasar teologinya diambil dari sejumlah sarjana salafi klasik, termasuk Ahmad ibn Hanbal (780855), Ahmad ibn Taimiyyah (1263-1328), dan Muhammad ibn Qayyim al-Jawziyya (12921350). ${ }^{7}$ Rujukan mereka selain kepada ketiga sarjana salafi klasik juga mengikuti fatwa yang dikeluarkan oleh ulama-ulama Salafi-Wahhabi kontemporer seperti Abd al-Aziz bin Baz (w. 1999) dan Muhammad Nasir al-Din al-Albani (w.1999). ${ }^{8}$

Pengaruh Arab Saudi di Indonesia terutama melalui Dewan Dakwah Islam Indonesia (DDII) yang didirikan pada 1967 oleh Muhammad

${ }^{6}$ Lihat Noorhaidi Hasan.2008. "The Salafi Madrasas of Indonesia", dalam Farish A.Noor, Yoginder Sikand \& Martin van Bruinessen (eds), The Madrasa in Asia: Political Activism and Transnational Linkage, Amsterdam, ISIM Series on Contemporary Muslim Societies, Amsterdam University Press, h. 449

${ }^{7}$ Wahabisme berbeda dari gerakan lainnya yang secara umum terkenal sebagai salafisme yang kemunculannya sekitar satu abad setelah gerakan Wahhabi. Gerakan ini adalah reformis-modernis yang diasosiasikan dengan Jamal al-Din al-Afghani (1838-1898), Muhammad Abduh (1849-1905), dan Muhammad Rasyid Rida (1865-1935) yang juga mengkampanyekan kembali ke al-Qur'an dan hadits tetapi menggunakan intrepretasi rasional.

${ }^{8}$ Noorhaidi Hasan, Op.Cit., h.249- 250
Natsir dan pemimpin pendiri Masyumi. Karena Natsir memiliki hubungan personal dengan elitelit Arab Saudi, DDII mendapat dukungan Arab Saudi dalam pengembangan kegiatan dakwah termasuk pembangunan masjid, lembaga pendidikan Islam, distribusi al-Quran, literatur Islam lainnya, dan latihan para da'i. Pengaruh yang intensif dari DDII dirasakan juga secara kuat di kampus perguruan tinggi. Pada sisi lain, untuk membendung pengaruh revolusi Iran 1979 di Indonesia, Arab Saudi mendirikan Lembaga Ilmu Pengetahuan Islam dan Bahasa Arab (LIPIA) di Jakarta pada $1980 .^{9}$

Para alumni LIPIA pertama yang telah belajar di Arab Saudi dan mendapatkan suasana perang Afghanistan menandai lahirnya generasi muslim reformis baru di Indonesia yang mereka sebut sebagai "salafi". Mereka itu adalah Abu Nida, Ahmad Faiz Asifudin, dan Aunur Rafiq Ghufron. Sebelum belajar di LIPIA, mereka pernah belajar pada sistem pesantren dan madrasah yang berorientasi modernis. Beberapa dari mereka dilatih oleh DDII dan menguasai bahasa Arab dan mempelajari teks Arab baik klasik (turast) maupun modern (ashry) serta mengadopsi pandangan puritan. Selain ketiga orang diatas, muncul seorang yang memiliki profil yang berbeda yaitu Ja'far Umar Thalib. Ia bukanlah alumni universitas Timur Tengah tetapi ia mengenal dan memperkenalkan gerakan Salafi. Ia lahir dalam keluarga Hadrami dan tumbuh dalam suasana puritan Al-Irsyad dan pernah belajar di pesantren Persis sebelum melanjutkan belajar di LIPIA. ${ }^{10}$ Abu Nida dan Ja'far Umar Thalib pernah bergabung dalam salah satu faksi barisan Mujahidin Afghanistan, yakni faksi Jama'ah Ad-Da'wah ila Al-Qur'an wa Ahl Al-Hadits. Faksi ini adalah faksi Salafi pimpinan Syaik Jamilurrahman. ${ }^{11}$

${ }^{9}$ Ibid., h. 251

${ }^{10}$ Ibid., h. 252.

${ }^{11} \mathrm{Abu}$ Mujahid. 2012. Sejarah Salafi di Indonesia, Bandung, Toobagus Publishing, h. 146-147. Dalam barisan Mujahidin Afghanistan terdapat banyak faksi, diantaranya yaitu: Ittihad-e-Islamy (Abdurrabil Rasul Sayyaf), Hizbi-e-Islamy (Gulbudin Hekmatyar), Harakatul Islamy (Burhanudin Rabbani), dan termasuk faksi yang dimasuki Abu Nida dan Ja'far Umar Thalib. Namun 
Pesantren Salafi tertua adalah pesantren Ihya al-Sunnah yang didirikan di Yogyakarta pada 1994. Pesantren ini didorong untuk menjadi pusat gerakan Salafi di Indonesia. Selanjutnya diikuti oleh Pesantren al-Turats alIslami yang didirikan di Yogyakarta pada 1995. Antara tahun 1995-2000, banyak pesantren Salafi lain didirikan yang sebagian besar ikut Ja'far Umar Thalib seperti Pesantren alMadinah dan Pesantren Imam Bukhori di Solo, Minhaj as-Sunnah di Magelang, Lu'lu wal Marjan di Semarang, Ibn Taymiyyah di Banyumas, al-Furqan dan al-Manshurah di Kroya, Assunah di Cirebon, at-Athariyah di Temanggung, Ittiba' al-Sunnah di Sukoharjo, as-Salafy di Jember, Ta'zim al-Sunnah di Ngawi, al-Bayyinah di Gresik, al-Furqan di Cilacap, al-Furqan di Pekanbaru, Ibn Qayyim di Balikpapan, Pesantren Bin Baz, Pesantren Al-Ansar, Pesantren Difa' $u$ al-Sunnah di Yogyakarta dan Pesantren Ibn Taimiyyah di Solo. Ketika gerakan pecah ke dalam kelompok yang loyal kepada Abu Nida dan pengikut faksi Ja'far Umar Thalib dan pesantren yang pernah dilatih di Ihya al-Sunnah, hanya tiga pesantren utama yang merupakan milik faksi Abu Nida, yaitu: pesantren al-Turats al-Islami di Yogyakarta, Imam Bukhari di Solo, dan AsSunnah di Cirebon. ${ }^{12}$

Perpecahan gerakan Salafi di Indonesia mempengaruhi model pendidikan yang dikembangkannya. Pesantren Bin Baz yang didirikan Abu Nida, misalnya, mendapat dukungan pembiayaan dari Jam'iyyah Ihya al-Turats al-Islami, sebuah organisasi sosial keagamaan yang bermarkas di Kuwait yang juga membuka kantor di Jakarta. Pesantren ini memiliki sarana dan prasarana yang lengkap. Kurikulumnya memadukan antara materi agama dan umum. ${ }^{13}$ Sebaliknya, pesantren Salafi yang dikembangkan Ja'far Umar Thalib dan jaringannya menolak seluruh materi

sebelum masuk faksi Ad-Dakwah Ila Quran, Ja'far Umar Thalib pernah masuk faksi Gulbudin Hekmatyar dan Abdurrabil Rasul Sayyaf.

${ }^{12}$ Noorhaidi Hasan, Op.Cit., h. 254.

${ }^{13} \mathrm{Abdul}$ Muin, dkk. 2007. Pendidikan Pesantren dan Potensi Radikalisme,Jakarta, Prasasti, h. 110-124. non-agama dalam kurikulumnya. Sarana dan prasananya sangat sederhana. ${ }^{14}$ Noorhaidi Hasan melihat pesantren-pesantren Salafi tersebut berperan penting dalam akselerasi proses santrinisasi kelompok abangan. ${ }^{15} \mathrm{Abdul}$ Aziz menyebut pesantren-pesantren Salafi itu sebagai pesantren yang memiliki karakter kontrakultur (counter culture). ${ }^{16}$

\section{Orientasi Pendidikan}

Orientasi pendidikan diartikan dengan "image" dan "expectation" terhadap sistem pendidikan yang dibangun. Bagaimana pendidikan dipahami, dimaknai dan harapan apa yang diperoleh dengan pendidikan yang dibangun. Orientasi pendidikan sangat luas. Salah satunya dapat dilihat dari perspektif pendidikan. Dalam perspektif pendidikan, ada dua misi utama pendidikan. Konsep ini mengarahkan pada dua misi utama pendidikan, yakni sebagai misi preservation dan promoting social change. Peran preservation atau continuity antara lain peran sosialisasi, menjaga identitas kultural (cultural identity), menjaga dan melanggengkan tradisi dan budaya masyarakat dimana pendidikan berlangsung. Sementara misi mempromosikan perubahan sosial (promoting social change) bagaimana pendidikan mengajarkan beragam cara yang akan merubah masyarakat kepada perbaikan atau kemajuan, pendidikan sebagai wahana penyebaran pengetahuan, sain dan teknologi, nilai-nilai modernitas, berbagai keterampilan berbasis teknologi sampai pengembangan muatan ideologi. Semakin besar peran preservation atau continuity sebuah lembaga pendidikan akan cenderung konservatif, eksklusif kurang terbuka terhadap sistem di luarnya. Sebaliknya semakin besar peran promosi perubahan sosial (promoting scial change) sebuah lembaga

\footnotetext{
${ }^{14} \mathrm{Abu}$ Mujahid, Op.Cit. h. 196.

${ }^{15}$ Noorhaidi Hasan, Op.Cit., h. 264.

${ }^{16}$ Lihat Kata Pengantar Abdul Aziz. 2011."Dari Subkultur Menuju Kontrakultur: Kontroversi Al-Zaytun sebagai Pesantren", dalam Tim Peneliti INSEP, Al-Zaytun: The Untold Stories, Jakarta, Pustaka Alvabet.
} 
pendidikan akan cenderung terbuka terhadap sistem di luarnya. ${ }^{17}$

Perkembangan dan beragamnya model pesantren memiliki kaitan dengan perkembangan pemikiran keagamaan yang terjadi di dunia Islam. Dalam era globalisasi arus informasi dunia Islam dan perkembangan pemikiran agama dengan mudah merambah ke mancanegara termasuk masyarakat muslim di Indonesia. Mudah dipahami bila muncul sejumlah pesantren yang orientasi pendidikannya beragam. Perkembangan pesantren sendiri selain memperlihatkan transformasisistem pendidikanjuga merupakan refleksi dari peta pemikiran keagamaan yang ada bukan saja pada skala lokal, nasional tetapi juga internasional.

Bentuk orientasi pendidikan sebuah pesantren terlihat lebih diwarnai oleh pemahaman keagamaan pimpinan pesantren (kiai) sebagai pemimpin karismatik yang mengajarkan paham keagamaan dan sekaligus sebagai panutan dalam pemikiran, sikap dan prilaku santri. Kiai sebagai elemen yang paling esensial dari sebuah pesantren, yang dengan kelebihan ilmunya dalam Islam, seringkali dilihat sebagai orang yang senantiasa dapat memahami keagungan Tuhan dan rahasia alam hingga mereka dianggap memiliki kedudukan yang tak terjangkau oleh kebanyakan masyarakat awam. ${ }^{18}$

Perkembangan pemikiran dan pemahaman keagamaan yang beragam dari pimpinan pesantren pada akhirnya akan melahirkan orientasi pendidikan dan nilainilai budaya pesantren yang sangat beragam. Dengan kata lain perkembangan pesantren merupakan refleksi dari peta pemahaman dan arus pemikiran keagamaan yang melahirkan pandangan hidup, sikap dan prilaku para santri yang sangat beragam pula.

${ }^{17}$ Tentang konsep ini lihat John Jarolimek, The Schools in Contemporary Society: An Analysis of Social Currents, Issues, and Forces, New York, Macmillan Publishing Co., INC, 1981, hal. 5-8. Khususnya bagian "Dynamic of SchoolSociety Relationships".

${ }^{18}$ Lihat Zamakhsyari Dhofier. 1982. Tradisi Pesantren: Studi tentang Pandangan Hidup Kyai. Jakarta, LP3ES.
Salah satu model pesantren hasil pemikiran dan pemahaman keagamaan dari pendiri dan pimpinan yang membentuk satu orientasi pendidikan dan satu nilai budaya adalah pesantren salafi, salah satunya Assunah. Hal ini mengacu kepada hasil penelitian Noorhaidi Hasan bahwa Assunah termasuk salah satu Pesantren Salafi faksi Abu Nida.

Selain menyelenggarakan kegiatan pendidikan, Assunah juga menyelenggarakan kegiatan dakwah dan sosial, maka dapat dibaca bahwa Assunah ini merupakan perwujudan dan cita-cita bahkan ideologi Salafi. Melalui misi pendidikan baik-misi preservation dan sosialisasi-yang dijalankan Assunah lambat laun akan membentuk "sebuah kultur", dalam hal ini kultur salafi. Artinya, kultur salafi inilah yang akan ditransmisikan Assunah dalam berbagai aktivitasnya.

Bingkai (framing) kultur Salafi-meminjam konsep religious movement-yang menempel pada Assunah adalah sebuah nilai dan budaya. Konsep tentang "cultural transmission" dan "cultural conflict" dapat digunakan untuk menjelaskan kasus Assunah. Menurut Foley ${ }^{19}$ konsep ini sering diadopsi dalam penelitian antropologi tentang sistem pendidikan di negara-negara berkembang. Umumnya pertanyaan yang menjadi perhatian para antropolog adalah kadar kemoderenan sekolahsekolah melakukan baik kontinuitas kultural (cultural continuity) atau diskontinuitas kultural (cultural discontinuity) melalui sosialisasi. Biasanya pertanyaan yang diajukan apakah sekolah-sekolah menjaga dan mempertahankan pengetahuan tradisional, nilai, norma, dan prilaku kultural yang dimilikinya atau menyesuaikan masyarakat tradisional kepada kemoderenan, nasional, identitas-identitas kultural, pengetahuan, nilai-nilai, norma, dan prilaku. Biasanya para antropolog mempelajari pengaruh sekolah-sekolah yang bersifat penjagaan dan penyesuaian. Studi-studi tersebut mencoba memahami pesan dan model

${ }^{19}$ Lihat Douglas E. Foley. 1997. "Anthropological studies of Schooling in Developing Countries: Some Recent Findings and Trend", dalam Comparative Education Review, Vol.21,Nod. 2 \& 3, June/October, 1997. 
cultural transmission yang dilakukan sekolah. Tipe data dalam studi kasus antropologi di sekolah-sekolah biasanya bukan kuantitatif dalam bentuk statistik, tetapi mereka seringkali memiliki kekuatan yang besar tentang kehidupan sehari-hari di sekolah.

Pengaruh penyesuaian dan integrasi dari sistem sekolah, menurut Foley dapat dikelompokan kepada: pertama, pengaruh yang kecil kepada individu atau struktur-struktur sosial, kedua, pengaruh yang kuat kepada gangguan nilai dan institusi tradisional serta pengaruh kuat kepada pengenalan nilai dan identitas modern, atau pengaruh yang kuat kepada reproduksi hubungan paternalistik dan struktur kelas, dan ketiga, pengaruh mediasi kepada individu-individu atau struktur sosial komunitas di komplek, dan secara terpaksa melakukan proses evolusi kultural atau proses pembangunan nasional.

Bagaimana prospek kultur salafi Assunah yang formalis dalam seluruh kegiatannya di masa depan. Menarik meminjam perspektif tentang perubahan Islam syariat dengan sikapnya yang militan, ideologis, dan serba formalis. Gerakan Islam akan berubah daya militansi dan doktrinernya ketika berhadapan dengan dunia nyata yang bersifat praktis dan pragmatis. jika ingin berubah sikap militan dan formalis, para aktivis Islam syariat terdapat tiga jalur penting, yakni sekolahkan mereka ke Barat, masukan ke panggung politik atau pemerintah, dan hadapkan pada dunia nyata. ${ }^{20}$ Hal ini juga bisa berlaku untuk kasus prospek kultur salafi Assunah yang formalis dalam seluruh kegiatannya di masa depan.

${ }^{20}$ Haedar Nashir.2007. Gerakan Islam Syariat: Reproduksi Salafiyah Ideologis di Indonesia, Jakarta, h. Xvixvii. Sebenarnya, menurut Nashir, perspektif ini diambil dari pernyataan Mahfud MD saat ujian disertasi Natsir maupun lewat tulisan kolomnya di salah satu media yang mempertanyakan tentang perubahan sikap militan, ideologis, dan serba formalis kelompok Islam Syariat.

\section{METODOLOGI PENELITIAN}

Penelitian ini merupakan studi kasus dengan sasaran Pesantren Assunah yang termasuk model pesantren Salafi. Sebagai studi kasus diupayakan agar peneliti mampu mengungkap secara lengkap dalam bentuk deskriptif analitis untuk menjawab permasalahan penelitian, sehingga mampu menjelaskan orientasi pendidikan di Pesantren Assunah tersebut.

Teknik pengumpulan data lebih mengandalkan pada studi kepustakaan, kemampuan melacak sumber literatur terkait, dokumen/ arsip sejarah, hasil penelitian, jurnal dan sumber data sekunder lainnya. Keberhasilan studi kepustakaan akan sangat mempengaruhi keberhasilan penelitian lapangan.

Penelusuran data primer dilakukan melalui wawancara dengan sejumlah nara sumber kunci (key informan), pelaku/aktor, mereka yang terlibat dengan berbagai peran yang dimiliki. Jumlah narasumber tidak dibatasi, tetapi dibatasi dengan kecukupan data dan informasi yang diperlukan untuk menjawab permasalahan penelitian.

Observasi dilakukan untuk mengangkat realita secara lebih utuh dengan tetap menggunakan pendekatan emik, artinya peneliti berupaya menangkap dan memahami fenomena yang ada, sebagaimana komunitas Assunah memaknai realitas tersebut. Observasi dilakukan terhadap semua kegiatan termasuk penyelenggaraan pendidikan di Assunah. Observasi dilakukan juga terhadap proses belajar mengajar di kelas, shalat berjamaah, kegiatan olahraga, orang tua yang mengantarkan anaknya ke sekolah (khusus orang tua TKIT dan SDIT), penataan asrama putra dan putri, warung, koperasi, dan studio radio. Pengumpulan data ini dilaksanakan oleh Peneliti Puslitbang Pendidikan Agama dan Keagamaan yang terdiri dari; Husen Hasan Basri, Abdul Mu'in, dan Ta'rif dengan dibantu oleh peneliti lokal yang direkrut dari dosen IAIN Syekh Nurjati Cirebon. 
Data dan informasi yang terkumpul dikoding dan direduksi kemudian dianalisa sesuai dengan formula kerangka konsep dua misi utama pendidikan, yakni sebagai misi preservation dan promoting social change, dan konsep cultural transmission. Hasil analisis ini selanjutnya diinterpretasi. Hasil analisa dan interpretasi tersebut tersaji dalam "hasil dan pembahasan" berikut.

\section{HASIL DAN PEMBAHASAN}

\section{Pendidikan di Assunah: Antara Misi Preservation dan Promoting Social Change}

Kesan pertama kali memasuki Assunah adalah sebuah kompleks dan komunitas pendidikan dengan segala aktivitasnya. Melalui pengadopsian pendidikan formal dari jenjang TK sampai MA, Assunah menawarkan sebuah pendidikan yang sesuai dengan kebutuhan masyarakat, perkembangan iptek dan nilainilai modernitas. Sebuah pendidikan yang seimbang dan terpadu antara dimensi moral, intelektual dan keterampilan atau pendidikan yang seimbang dan terpadu antara penguasaan dan pengamalan ilmu-ilmu agama dan iptek yang didasari oleh nilai-nilai moral agama.

Strategi Pendidikan yang dilakukan Assunah berusaha menggali dan mengembangkan potensi peserta didik berbasis kecerdasan hati, akal dan spritual melalui pengintegrasian mata pelajaran Iptek dan Imtak dengan mendorong kreativitas dan kemampuan peserta didik untuk terus meningkat lebih optimal. Assunah memberikan tekanan dalam pendidikannya pada regenerasi moral masyarakat sebagai persyaratan utama bagi pengembangan kehidupan material, karena pada dasarnya mereka tidak menolak akumulasi kapital dan model kehidupan yang makmur.

Untuk mengoptimalkan strategi pendidikan tersebut, Assunah menggunakan sistem full day school untuk Taman Kanak-Kanak Islam Terpadu (TKIT) dan Sekolah Dasar Islam Terpadu (SDIT) sejak kedua jenjang pendidikan itu didirikan masing-masing pada 1995 dan
1996. Selain menggunakan sistem full day school, Assunah menerapkan sistem boarding school untuk jenjang Madrasah Tsanawiyah (MTs) yang didirikan pada 2004. Sistem boarding school ini juga diterapkan untuk jenjang Madrasah Aliyah (MA) yang didirikan pada 2007. Adanya sistem full day school dan sistem boarding school menjadi salah satu alasan banyak masyarakat Kota Cirebon yang menyekolahkan anakanaknya ke lembaga pendidikan Assunah. Mereka berasal dari kalangan pejabat, pengusaha, tokoh masyarakat, boleh dikatakan Assunah memiliki segmen pasar dari kalangan menengah keatas. ${ }^{21}$ Penerapan sistem full day school dan boarding school menunjukkan bahwa pendidikan di Assunah diorientasikan kepada keinginan dan ekspektasi masyarakat. Sistem ini berkembang dan diadopsi oleh beberapa SMA "unggulan" di Indonesia.

Grafik 1: Perkembangan santri atau siswa Assunah pada berbagai jenjang pendiidkan formal dalam lima tahun terakhir

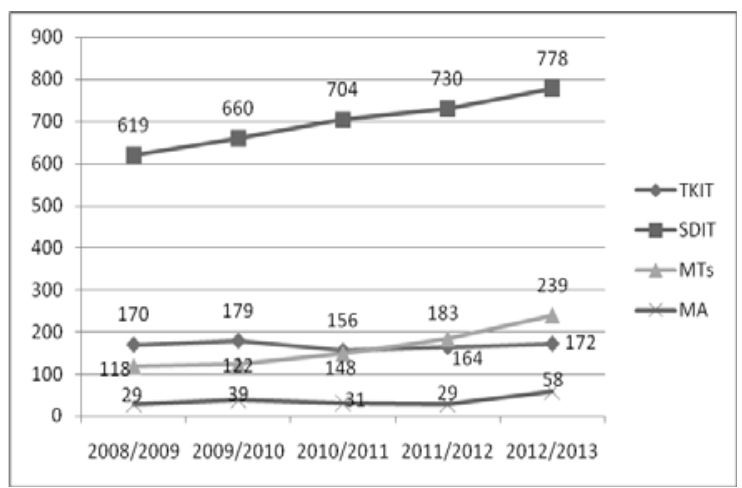

Sumber: Diolah dari Dokumen Bidang Pendidikan Assunnah 2012

Berdasarkan Grafik 1, dalam lima tahun terakhir ini perkembangan santri atau siswa pendidikan formal di Assunah mengalami kenaikan, kecuali TKIT yang mengalami naikturun-naik-naik, dan MA yang mengalami naikturun-turun-naik. Perkembangan kenaikan yang tajam terjadi pada jenjang SDIT. Selama 16 tahun dari sejak berdirinya tahun 1996 jumlah siswa SDIT Assunah sudah mencapai 778 orang.

${ }^{21}$ Hasil wawancara dengan Prof. Dr. Adang Djumhur (Guru Besar IAIN Cirebon) tanggal 4 Desember 2012. 
Melihat data jumlah dan perkembangan siswa dan santri diatas, ada kecenderungan orangtua lebih mengutamakan fullday school untuk menitipkan anaknya dengan aman dan nyaman, pergi ke kantor anak diantar dan pulang dari kantor anak dijemput, tentunya juga mendapatkan pendidikan agama. Hal ini dapat dilihat dari SDIT yang menempati jumlah siswa terbanyak dan jumlah siswa TKIT yang cukup banyak. Sedangkan jumlah siswa MTs dan MA sangat jauh berbeda dengan jumlah siswa pada SDIT. Kalaulah orangtua betul-betul mengutamakan "pendidikan agamanya" maka jumlah siswanya baik pada TKIT, SDIT, MTs maupun MA tidak terlalu jauh berbeda.

Kondisi ini diasumsikan, pertama, orangtua lebih mengutamakan penanaman aqaidah dan akhlakul karimah pada anak usia dini, sementara pada anak usia MTs dan MA orangtua memberi kebebasan untuk memilih dan menentukan sekolah (selain Assunnah) dengan alasan anaknya sudah memiliki dasardasar aqidah. Kedua, anak yang sejak TKIT dan SDIT sudah mulai bosan di Assunnah, sehingga pada jenjang MTs dan MA pindah untuk mencari dan menikmati suasana yang lain. Tapi, seandainya orang tua betul-betul mengutamakan pendidikan agama, mustahil orang tua membiarkan anaknya pindah dari Assunnah.

Assunah memiliki santri yang berasal dari Program I'dad Du'at (Persiapan Da'i). Program ini ditempuh selama 2 tahun dan santrinya berasal dari SMA dengan beasiswa dari pondok pesantren. Rekrutmen calon santri program ini melalui tes (seleksi) yang ketat, sebab santrinya sangat terbatas hanya 10 orang setiap angkatan. Sekarang ini sudah mencapai 7 angkatan dan semuanya laki-laki.

Orientasi pendidikan kepada misi mempromosikan perubahan sosial (promoting social change) dapat dilihat dari keberadaan yayasan,strukturorganisasi, dankepemimpinan di Assunah. Assunah merupakan sebuah yayasan dengan Akta Notaris Atiyah Djahari,
SH Nomor 17 tertanggal 15 Oktober 1993.22 Karena itu bidang pendidikan dan seluruh kegiatan yang diselenggarakan Assunah berada di bawah yayasan Assunah. Pengelolaan pendidikan di Assunah dilakukan secara terukur dan terorganisir secara baik. Di Assunah terdapat Kabid Pendidikan yang dijabat ustadz Muhyiddin, S.Pd bertugas merencanakan, melaksanakan dan mengevaluasi seluruh aktivitas pendidikan. Pengalaman ustadz Muhyiddin, S.Pd yang merupakan alumni UPI Bandung dan pernah mengabdi di Perguruan Al-Azhar Cirebon selama 12 tahun, merancang seluruh aktivitas Assunah dalam bidang pendidikan. Apa yang telah dialami saat di AlAzhar dan pengalamannya studi banding di beberapa lembaga pendidikan, ia praktekkan di Assunah. Kabid Pendidikan dibantu oleh beberapa kepala Unit (Kanit), yaitu: Kanit Pondok Pesantren, Kanit TK, Kanit SD, Kanit MTs, dan Kanit MA.

Sebenarnya Assunah ini lebih merupakan sebuah perguruan yang berada di bawah yayasan dengan suasana pendidikan formalnya, dari pada bercorak pesantren sebagaimana pesantren-pesantren pada umumnya baik pesantren Salafiyah (tradisional) maupun pesantren modern (khalafi). Misalnya Prof. Abdullah Ali, Guru Besar IAIN Nurjati Cirebon, dalam wawancara dengan peneliti mengatakan bahwa Assunah baru menapak bahkan menggagas menjadi sebuah pesantren. ${ }^{23}$ Namun Assunah tetap diperlakukan sebagai pesantren karena, pertama, mereka sendiri menamakan pesantren, kedua, sudah terdaftar di Kemenag kota Cirebon sebagai pesantren di Kasi PD dan Pesantren ${ }^{24}$ dan ketiga, di dalamnya terdapat

${ }^{22}$ Akta Notaris Atiyah Djahari, SH Nomor 17 tertanggal 15 Oktober 1993 diperbaharui melalui Akta Notaris Saleh Bafadal, SH Nomor 4 tertanggal 6 April 2005 kemudian diperbaharui kembali melalui Akta Notaris Nomor 16 tertanggal 24 November 2006 yang juga dibuat Notaris Saleh Bafadal, SH. Selain itu, Assunnah telah mendapat pengesahan oleh Menteri Hukum dan Hak Asasi Manusia RI dengan Surat Keputusan Nomor C. 2924 HT 01. 02 Tanggal 13 Desember 2006.

${ }^{23} \mathrm{Hasil}$ wawancara dengan Prof. Ali (Guru Besar IAIN Cirebon), 4 Desember 2012.

${ }^{24} \mathrm{Hasil}$ wawancara dengan Kepala Kandepag Kota Cirebon dan staf Kasi PD \& Pontren Kemenag Kota 
unsur-unsur yang memenuhi ciri-ciri umum pesantren, seperti adanya masjid, pondok, kiai, ustadz, santri, dan pengurus yang hidup dalam satu kampus, dan di dalamnya juga diselenggarakan pengajian kitab-kitab keagamaan Islam, meskipun sebagian besar kitab adalah kitab ashry.

Kepemimpinan di Assunah menggunakan sistem kolektif-kolegial di mana setiap bidang dan unit bekerja sesuai dengan tugas dan fungsinya masing-masing. Kepemimpinan di Assunah dapat dikategorikan menganut kepemimpinan free rein leadership (laiser faire), di mana pemimpin pasif, sebagai seorang bapak yang memberikan kesempatan kepada anakanaknya untuk berkreasi. Tidak semua urusan diserahkan kepada ustadz Toharoh, Lc sebagai ketua Badan Pengurus dan sekaligus pimpinan pesanten. Urusan-urusan diserahkan kepada bidang-bidang kegiatan sesuai dengan struktur organisasi. Ia diperlukan saat muncul masalah yang dianggap besar dan perlu diselesaikan yang melibatkan dirinya.

Pergantian pimpinan di Assunah lebih didasarkan musyawarah diantara Badan Pembina, Badan Pengurus, dan Badan Pengawas. Karena Assunah berbentuk yayasan, menurut Ustdaz Said Riyana bisa saja Assunah bubar atau membubarkan diri. Rekruitmen kepemimpinan didasarkan pada kemampuan bukan kepada senioritas dan kekeluargaan.

Bentuk lain yang dapat dikategorikan bahwa pendidikan di Assunah diorientasikan kepada misi mempromosikan perubahan sosial (promoting social change) adalah interaksi yang terbuka dengan sistem di luarnya. Misalnya, selain kerjasama dengan Kementerian Agama dan Kementerian Pendidikan, Assunah juga melakukan kerjasama dengan Kementerian Hukum dan HAM melalui Rumah Tahanan Kota Cirebon. ${ }^{25}$ Pesantrenmelakukan pembinaanbagi

Cirebon, 3 Desember di ruang kerja.

${ }^{25}$ Kerjasama ini bermula dari kunjungan Isteri Menteri Hukum dan HAM saat itu Patrialis Akbar, dalam kunjungan tersebut isteri menteri Hukum dan HAM tertarik dakwah yang dilakukan Assunnah dan kemudian meminta untuk membina bagi para tahanan yang ada di kota Cirebon. Setiap harinya para ustadz Assunnah para tahanan terutama dalam hal pembinaan mental spiritual. Melalui kerjasama ini pesantren akhirnya membuka semacam cabang pesantren di Rutan Kota Cirebon, tepatnya dua tahun yang lalu. Assunah juga melakukan kerjasama dengan dinas pertanian dan peternakan. Assunah mendapatkan pelatihan dan pembinaan dalam hal pengembangan ekonomi, bantuan ini tidak sekedar diklat tetapi juga bantuan modal. Misalnya Assunah mengembangkan peternakan ikan lele yang berlokasi di Assunnah 2. Saat ini terdapat kolam ikan lele dari mulai penetasan sampai besar untuk dijual ke pasar. Pengembangan ekonomi ini merupakan bentuk pembelajaran sekaligus sumber pendanaan Assunah.

Seiring dengan munculnya kesan negatif yang ditujukan kepada Assunah seperti memiliki potensi radikal dan beberapa kejadian yang dialamatkan Assunah oleh media maupun masyarakat, gerak dan langkah Assunah mendapatkan pemantauan terutama dari pihak keamanan (kepolisian/intel). Kedatangan para pihak keamaanan sering melakukan pemantauan baik langsung maupun tidak langsung. Dengan demikian secara tidak langsung dapat dikatakan bahwa Assunah selalu melakukan komunikasi aktif dengan pihak keamanan. Dari komunikasi ini Assunah berusaha memberikan penjelasan-penjelasan secara baik yang terkait dengan tuduhantuduhan yang dialamatkannya maupun paham yang dikembangkannya. Hubungan komunikasi ini membawa dampak positif bagi Assunah, karena beberapa tuduhan miring yang ditujukan Assunah tidak terbukti, walaupun dalam hal-hal tertentu masih perlu dijelaskan kepada masyarakat.

Di Assunah dapat disaksikan sarana dan prasarana pendidikan yang cukup lengkap yang ditata secara baik. Secara umum sarana

mendapatkan jadwal pembinaan dengan kurikulum yang telah dibuat pesantren. Kegiatan pembinaan dilakukan selama dua jam setiap harinya dengan diikuti sebanyak 500 orang. Dari hasil pembinaan ini banyak perubahan di kalangan para tahanan dan bahkan pesantren yang di Rutan ini menjadi model dan kemungkinan akan dikembangkan di tempat lainnya. 
dan prasarana yang dimiliki Assunah adalah: masjid Assunah untuk putra dan masjid Khadijah untuk putri, ruang kelas permanen, pusat sumber belajar, MCK, kantin, ruang asrama, sarana olahraga (bulu tangkis, futsal, volly ball), Waserda, Perpustakaan, halaman dan tempat parkir yang luas, ruang serba guna (auditorium), stasiun radio Assunah, rumah pimpinan dan para guru. Keberadaan dan kelengkapan sarana dan prasarana pendidikan di Assunah memperjelas bahwa pendidikan diorientasikan kepada mempromosikan perubahan sosial.

Namun demikian, tidak bisa dipungkiri Assunahmelakukanmisipreservationyangintens dan cukup terbuka. Ada nilai-nilai kultural yang berbeda dengan nilai-nilai kultur masyarakat di luarnya. Dengan latar Salafi yang dimilikinya, Assunah berusaha dan berupaya untuk menjaga identitas kultural (cultural identity) salafi ini. Karena itu pendidikan dimaknai oleh pimpinan dan pengurus inti Assunah bukan sekedar lembaga pendidikan yang didalamnya ada proses pembelajaran di kelas-kelas tetapi proses pembentukan nilai masyarakat muslim. Tidak berlebihan kalau Assunah ini dikategorikan meminjam istilah Anne Sofie Roald sebagaimana dikutip Arief Subhan sebagai "gerakan tarbiyah". ${ }^{26}$ Ini merupakan sebuah konsep gerakan islamisasi masyarakat yang melibatkan sebuah proses jangka panjang dan meliputi segala aspek kehidupan. Tarbiyah memang tidak semata-mata dimengerti sebagai lembaga pendidikan, tetapi meliputi seluruh perjuangan yang mengarah kepada proses pembentukan masyarakat muslim. Dibukanya program I'dadu Du'at dan program kegiatan dakwah lainnya sebagai bentuk menjalankan misi preservation ini. Pengadopsian "sistem pendidikan pesantren", yang sebenarnya bukan tradisi mereka, dalam rangka menjaga dan melanggengkan tradisi dan budaya masyarakat dimana pendidikan berlangsung. Adopsi sistem pendidikan pesantren hanya strategi

26 Lihat Arief Subhan. 2012. Lembaga Pendidikan Islam Indonesia Abad ke-20:Pergumulan Antara Modernisasi dan Identitas. Jakarta, Kencana, h. 272 untuk mengurangi resistensi dari sebagian masyarakat.

Semakin besar misi preservation sebuah lembaga pendidikan akan cenderung konservatif, eksklusif kurang terbuka terhadap sistem di luarnya. Sebaliknya semakin besar misi promoting social change, semakin terbuka mengadopsi sistem yang dianggap mendukung perubahan, kurikulum komprehensif, pembelajaran berbasis IT, dengan jenjang dan capaian yang lebih terukur dan relevan dengan tantangan yang dihadapi. Akhirnya, jika ditakar antara misi preservation dan promoting social change dalam konteks pendidikan di Assunah adalah Pendidikan Modern di pesantren berbasis Salafi. Realita ini menguatkan salah satu temuan penelitian Puslitbang Pendidikan Agama dan Keagamaan Tahun 2005 tentang pandangan hidup santri. Temuan penelitian itu menyebutkan sebagian besar santri (45,9\%) memandang pendidikan modern di pesantren merupakan pendidikan yang paling diinginkan. Hanya (19,3\%) dari santri yang menginginkan pendidikan Salafi atau semata-mata belajar agama (tafaqquh fiddin) yang dianggap ideal. Artinya, sebagian besar santri menginginkan sistem pendidikan yang mengandung unsur pendidikan modern dan kepesantrenan. Hal ini menunjukkan kecenderungan keterbukaan santri menerima sistem modern dalam artian pendidikan yang berorientasi modernitas dan berbasis iptek tapi tetap mempertahankan kultur pesantren. ${ }^{27}$

\section{Pendidikan di Assunah dan Orientasi Kultur Salafi}

Assunah tak bisa dilepaskan dari Salafi. Sejak pendiriannya, Assunah diprakarsai oleh orang-orang yang pernah aktif dalam kegiatan kelompok-kelompok diskusi dan kajian usrah dengan sistem sel networking, dan pernah belajar di lembaga pendidikan Islam yang bernama 'Alamussunah di daerah Lewiliang Bogor (sekarang menjadi organisasi Harakah Sunniyah

${ }^{27}$ Fuaduddin, 2005, Laporan Penelitian Pandangan Hidup Santri, Puslitbang pendidikan Agama dan Keagamaan Badan Litbang dan Diklat Keagamaan, Jakarta. 
untuk Masyarakat Islami atau HASMI). Ormas HASMI ini berbeda dengan kelompok teror HASMI yang dirilis polisi yang singkatannya Harakah Sunny untuk masyarakat Indonesia. Baik kegiatan kelompok keagamaan usrah maupun pesantren 'Alamussunah mengajarkan manhaj Salafi. Alasan ketidaksetujuan dan melakukan "taubat nasuha", lebih dikarenakan kedua gerakan itu membawa misi ideologi Islam yang cenderung politis. Adanya beberapa alumni Universitas Madinah dan LIPIA Jakarta memperkuat sekaligus melapangkan jalan bagi Assunah untuk mempraktekkan manhaj salafi. Orang-orang inilah merupakan pengelola inti yang merancang seluruh aktivitas Assunah di berbagai bidang kegiatan.

Dengan mengembangkan sejarahnya sendiri, Assunah didirikan sebagai hasil dari interaksi pemikiran dan gerakan yang selama ini mereka lakukan. Eksistensi Assunah dengan berbagai kegiatan baik dakwah, pendidikan, dan sosial adalah bentuk implementasi kesadaran dan pertaubatan dari gerakan yang mereka anggap keliru. Nilai-nilai kultural salafi yang memang sejak awal sudah terbingkai dalam proses interaksi pemikiran dan gerakan para pendiri menjadi cita-cita yang hendak diimplementasikan di Assunah. Nilai-nilai kultural salafi itu sebagaimana yang dikumandangkan oleh beberapa gerakan salafi adalah prinsip Tashfiyah (pemurnian aqidah) dan Tarbiyah (pembinaan umat). Medium untuk mengimplementasikan kedua prinsip itu adalah Assunah. Jika teks Assunah sebagai media, maka cita-cita "mentashfiyahkan" dan "mentarbiyahkan" sebagai tujuannya.

Penamaan lembaga dengan nama Assunah sendiri bisa menjadi petunjuk awal untuk melakukan upaya tashfiyah dan tarbiyah. Karenanya tujuan "penanaman akidah yang lurus" menjadi prioritas pertama dari rumusan tujuan pendidikan Assunah. Meskipun dalam rumusan tujuan dicantumkan kata-kata cerdas, kreatif, terampil, sehat, disiplin yang mengarah kepada nilai-nilai modenitas yang positif, hal itu akan dibungkus dengan rumusan tujuan terakhir yakni berfahamkan salafus sholeh.
Sampai di sini proses kontinuitas kultural salafi melalui proses pendidikan dimulai.

Bentuk kontinuitas kultural salafi selanjutnya bisa dilihat dari visi dan misi Assunah. Sebagaimana telah dijelaskan, visi Assunah yaitu terwujudnya masyarakat yang taat beribadah hanya kepada Allah SWT berdasarkan al-Quran dan as-Sunah menurut pemahaman salafus sholeh. Visi salafi ini melandasi visi-visi lembaga baik pendidikan formal seperti MTs dan MA maupun program pendidikan lainnya seperti program I'dad Du'at dan Tarbiyatu Nisa; lembaga dakwah dan lembaga sosial. Bahkan bentuk kontinuitas kultural salafi secara mencolok dalam misi yang dijalankan Assunah. Secara eksplisit, Assunah menjalankan misi menyelenggarakan dakwah islamiyah melalui tashfiyah (pemurnian ajaran Islam) dan tarbiyah (pembinaan berkesinambungan). Misi Assunah ini dirinci ke dalam berbagai program kegiatan.

Misi berbagai program pendidikan di Assunah memiliki jenjang misi keagamaan yang ingin dijalankan. Misi keagamaan pada pendidikan usia dini (TKIT) dan SDIT baru sebatas dasar pembentukan dan pengembangan anak didik seperti "beriman", "Islam dengan pemahaman yang benar", dan "nilai-nilai akhlak islami", sedangkan misi keagamaan pada pendidikan MTs dan MA lebih meningkat dalam pembentukan dan pengembangan keagamaan seperti "bertauhid beribadah hanya kepada Allah", "pembelajaran al-Qur'an dan asSunnah dengan pemahaman Salaful Ummah" dan "semangat dakwah Islam". Semua jenjang misi ini merupakan bagian tak terpisahkan dari salah satu misi pesantren Assunah, yakni: tashfiyah (pemurnian ajaran Islam) dan tarbiyah (pembinaan berkesinambungan). Meskipun ada misi yang diorientasikan pada upaya penyesuaian dengan sistem pendidikan nasional, tidak sedikit pendidikan di Assunah dibumbuhi manhaj salafi.

Simbol dan praktek (termasuk ritual ibadah) keagamaan Salafi masih nampak terlihat di Assunah. Meskipun tidak seluruhnya, para pengurus yayasan, para ustadz, dan staf mengunakan jalabiyah untuk laki-laki dan 
niqab untuk perempuan. Buku-buku ajar yang digunakan terutama pada tingkat MTs dan MA adalah buku-buku ajar berbahasa Arab yang secara genealogis dan jaringan intelektual mengambil dari para ulama Salafi-Wahhabi seperti Dr. Shaleh Fauzan bin Abdullah alFauzan (Komite Fatwa Tinggi Kerajaan Arab Saudi) dengan bukunya Al-Mulakhos fi syarhi Kitab at-Tauhid. Kitab ini merupakan ringkasan dari kitab Tauhid nya karangan Muhammad bin Abdul Wahhab. Dan sampai saat ini, Assunah masih berhubungan dengan jaringan Salafi Indonesia, salah satunya melalui pengiriman ustadz-ustadz dalam kegiatan daurah yang diadakan di Jakarta mungkin penyelenggaranya Yayasan Al-Khairiyah Al-Musyarakah atau Yayasan At-Turast yang mana kedua Yayasan tersebut ikut terlibat dalam pendanaan Pesantren-pesantren Salafi faksi Abu Nida. Dan, Assunah pernah mendapat bantuan dana dalam dari Yayasan Al-Khairiyah Al-Musyarakah dalam salah satu pembangunan sarana dan prasarana pendidikan Assunah.

Apa yang telah penulis paparkan menunjukkan teks Assunah dengan segala aktivitasnya sedang memerankan kontinuitas kultural salafi. Tetapi, kontinuitas kultural salafi ini belum berpengaruh secara kuat kepada individu atau struktur sosial di luar lingkungan Assunah berada. Tentang pengaruh kontinuitas kultural salafi Assunah terhadap sistem di luar Assunah barangkali perlu ada kajian dan studi lebih lanjut.

Bagaimana prospek kultur salafi Assunah yang formalis dalam seluruh kegiatannya di masa depan dikaitkan dengan sistem pendidikan nasional. Berdasarkan UU No. 20 Tahun 2003 dan PP 55 Tahun 2007 pesantren telah memperoleh pengakuan sebagai bagian dari sistem pendidikan nasional. Sebagai bagian dari sistem pendidikan nasional, maka tujuan pendidikan di pesantren harus mengacu dan sejalan dengan tujuan pendidikan nasional "mengembangkan potensi peserta didik menjadi manusia yang beriman dan bertakwa kepada Tuhan Yang Maha Esa dan berakhlak mulia, sehat, berilmu, cakap, kreatif, mandiri, dan menjadi warganegara yang demokratis dan bertanggung jawab". Dalam PP 55 Tahun 2007 secara eksplisit dirumuskan "Pesantren adalah lembaga pendidikan berbasis masyarakat yang menyelenggarakan pendidikan keagamaan Islam dalam pondok pada jalur pendidikan formal dan nonformal. Lebih lanjut dalam PP tersebut disebutkan bahwa Pesantren sebagai pusat pendidikan Islam dapat menyelenggarakan pendidikan terpadu dengan pendidikan umum dan/atau kejuruan pada tingkat dasar, menengah dan tinggi."

Prospek kultur salafi Assunah yang formalis dalam seluruh kegiatannya di masa depan secara evolutif akan mengalami perubahan jika dihadapkan kepada dunia nyata yang bersifat praktis dan pragmatis. Misalnya jika Assunah secara tegas mengakui, mengacu, mengikuti dan mengimplementasikan Sistem pendidikan nasional, khususnya standar nasional pendidikan. Hal ini sebagaimana terjadi pada Gerakan Islam yang awalnya memilki daya militansi dan bersifat doktriner berubah ke arah yang bersifat praktis dan pragmatis melalui tiga jalur penting seperti yang disebutkan Mahfudz MD, yakni sekolahkan mereka ke Barat, masukan ke panggung politik atau pemerintah, dan hadapkan pada dunia nyata. ${ }^{28}$

\section{PENUTUP}

\section{Kesimpulan}

1. Pendidikan di Assunah dipahami bukan sekedar membangun lembaga pendidikan tetapi pendidikan dalam makna yang lebih luas, yakni pembinaan masyarakat Islam, karenanya pendidikan di Assunah lebih diorientasikan kepada dakwah dalam bentuk (tashfiyah) melalui jalan membina umat (tarbiyah) yang ini merupakan prinsip manhaj salafi. Karenanya, tujuan, visi, dan misi pendidikan yang hendak dibangun dan dijalankan adalah mengarah kepada manhaj salafi. Manhaj salafi ini mewarnai seluruh aktivitas Assunah. Karena itu

${ }^{28}$ Lihat Haedar Nashir. 2007. Gerakan Islam Syariat: Reproduksi Salafiyah Ideologis di Indonesia, Jakarta, h. Xvixvii. 
hampir semua aktivitas pendidikan di Assunah mengarah kepada kontinuitas kultur salafi.

2. Kontinuitas kultural salafi masih nampak di Assunah baik dalam kegiatan pendidikan, dakwah, dan sosial. Konsekuensi ini akibat dari pendidikan yang dijalankan Assunah lebih besar misi preservation dari pada misi promoting social change. Kontinuitas kultural salafi ini dimungkinkan akan berubah, jika aktivitas pendidikan Assunah lebih mengacu kepada sistem pendidikan nasional, khususnya lagi mengacu kepada delapan standar nasional pendidikan.

3. Munculnya resistensi terhadap Assunah berasal dari penyebaran paham SalafiWahhabi yang dilakukan Assunah secara massif melalui ceramah, tabligh, majalah, dan radio. Hal ini dikhawatirkan oleh kelompok yang kontra dapat meresahkan masyarakat yang telah memiliki paham keagamaaan mainstream.

\section{REKOMENDASI}

1. Pengadopsiansistempesantrenyang dilakukan Assunah perlu mendapat dorongan dan pembinaan dari Kementerian Agama sehingga unsur-unsur yang memenuhi ciriciri umum pesantren bisa lebih terpenuhi.

2. Unsur-unsur yang kontra produktif terhadap wawasan kebangsaan dan proses demokratisasi dalam proses kegiatan pendidikan seperti kegiatan "upacara bendera model Assunah" yang khas harus diminimalisir kalau perlu dihilangkan dari proses pendidikan.

3. Penyebaran paham secara demonstratif perlu dirubah dengan metode dan pendekatan yang mengedepankan prilaku dan sikap toleransi kepada masyarakat.

4. Sebagai model pesantren Salafi, pembinaan Assunah dan pesantren Salafi lainnya perlu dibedakan dengan pembinaan modelmodel pesantren lainnya baik pesantren tradisional, pesantren modern, atau pesantren islamis.

\section{SUMBER BACAAN}

Bruinessen, Martin van (2008): "Traditionalist and Islamist Pesantren in Contemporary Indonesia", dalam Farish A.Noor, Yoginder Sikand \& Martin van Bruinessen (eds), The Madrasa in Asia: Political Activism and Transnational Linkage, Amsterdam, ISIM Series on Contemporary Muslim Societies, Amsterdam University Press.

Dhofier, Zamakhsyari (1994): Tradisi Pesantren : Studi tentang Pandangan Hidup Kyai. Jakarta, LP3ES.

Fuaduddin (2006): Laporan Penelitian Pandangan Hidup Santri, Jakarta, Puslitbang Pendidikan Agama dan Keagamaan, Badan Litbang Agama dan Diklat Keagamaan Departemen Agama.

Foley, Douglas E. (1997): "Anthropological studies of Schooling in Developing Countries: Some Recent Findings and Trend", dalam Comparative Education Review, Vol.21,Nod. 2 \& 3, June/October.

Hasan, Noorhaidi (2008): "The Salafi Madrasas of Indonesia", dalam Farish A.Noor, Yoginder Sikand \& Martin van Bruinessen (eds), The Madrasa in Asia: Political Activism and Transnational Linkage, Amsterdam, ISIM Series on Contemporary Muslim Societies, Amsterdam University Press.

Hasil wawancara dengan Ustadz Thoharoh, Ketua Yayasan sekaligus pimpinan pesantren Assunah, 24 Desember 2012.

Hasil wawancara dengan Ustad Muhyidin, 3 dan 21 Desember 2012.

Hasil wawancara dengan Ustadz Said Riyana, Sekretaris Yayasan Assunnah, 4 dan 5 Desember 2012.

Hasil wawancara dengan Prof. Ali, 4 Desember 2012. 
Hasil wawancara dengan Kepala Kandepag Kota Cirebon dan staf Kasi PD \& Pontren Kemenag Kota Cirebon tanggal 3 Desember di ruang kerja.

Hasil wawancara dengan Prof. Dr. Adang Djumhur (Guru Besar IAIN Cirebon), 4 Desember 2012.

Hasil wawancara dengan ustadz Diding Sobarudin, 4 Desember 2012.

Hasil wawancara dengan salah satu pengurus Diyaussunah, 4 Desember 2012.

Jarolimek, John (1981): The Schools in Contemporary Society: An Analysis of Social Currents, Issues, and Forces, New York, Macmillan Publishing Co., INC.

Nashir, Haedar (2007): Gerakan Islam Syariat: Reproduksi Salafiyah Ideologis di Indonesia, Jakarta.

Merdeka.com, Jumat (28/09) dalam rubrik khas wawancara dengan KH Said Aqil Siraj dengan tema "Ajaran Wahabi Mendorong Orang Menjadi Teroris".
Mujahid, Abu (2012): Sejarah Salafi di Indonesia. Bandung, Toobagus Publishing.

Subhan, Arief Subhan (2012): Lembaga Pendidikan Islam Indonesia Abad ke20:Pergumulan Antara Modernisasi dan Identitas. Jakarta, Kencana.

Suniti (2011): Laporan Penelitian Kurikulum Pondok Pesantren Assunah Kota Cirebon. Cirebon, IAIN Nurjati Cirebon.

Tim Peneliti Puslitbang Pendidikan Agama dan Keagamaan (2009): Pola Aktivitas Keagamaan Mahasiswa Islam Perguruan Tinggi Umum Negeri Pasca Reformasi. Jakarta, Badan Litbang dan Diklat Departemen Agama.

Tim Peneliti INSEP (2011): Al-Zaytun: The Untold Stories. Jakarta, Pustaka Alvabet. 